\title{
Drug therapy trials for the prevention of bronchopulmonary dysplasia: current and future targets
}

\author{
Vineet Bhandari* \\ Division of Perinatal Medicine, Department of Pediatrics, Yale University School of Medicine, New Haven, CT, USA \\ ${ }^{*}$ Correspondence: vineet.bhandari@yale.edu \\ Edited by: \\ Mary E. Sunday, Duke University Medical Center, USA \\ Reviewed by: \\ Andrew T. Lovering, University of Oregon, USA \\ Charles Christoph Roehr, Charité Universitätsmedizin Berlin, Germany \\ Matthew K. Lee, University of Southern California, USA
}

Keywords: newborn, clinical trials, drug therapy, lung, chronic lung disease

\section{A commentary on}

Bronchopulmonary dysplasia: NHLBI workshop on the primary prevention of chronic lung diseases

by McEvoy CT, Jain L, Schmidt B, Abman S, Bancalari E, Aschner JL. (2014). Ann Am Thorac Soc 11(Suppl 3):S146-53. doi: 10.1513/AnnalsATS.201312-424LD

Bronchopulmonary dysplasia (BPD), currently the most common chronic respiratory disease in infants, is a multifactorial disease secondary to genetic (1) and environmental factors (chief among them being exposure to invasive mechanical ventilation, ante- and postnatal infections, and hyperoxia) $(2,3)$. It is estimated that approximately 10,000-15,000 new cases of BPD occur each year in the United States, of which $97 \%$ occur in infants with birth weights $<1250 \mathrm{~g}$ (3). Over the last decade, the incidence of BPD has been reported variably to have decreased (4), remained the same (5), or even increased slightly $(3,6,7)$. However, there is uniform agreement that BPD is associated with significant resource utilization and increased costs $(4,8)$. While studies assessing the economic burden of BPD are mostly restricted to their initial hospitalization in neonatal intensive care units $(4,8)$, this is a chronic lung disease with significant pulmonary and neurodevelopmental sequelae $(3,9,10)$ that impacts healthcare costs into the pediatric age group $(11,12)$ and would be expected to continue to do so into adulthood (13).

Given the above data, novel effective drug therapies for the prevention of BPD would potentially make a significant difference in the health and costs for prematurely born children. A recent workshop conducted under the auspices of the National Heart Lung and Blood Institute of the National Institutes of Health on the primary prevention of chronic lung diseases focused on BPD (14). In terms of "promising near-term opportunities for primary BPD prevention research," specifically, "clinical research priorities and specific clinical trials for BPD prevention," it was disappointing to note that only two specific drugs were named: caffeine and inhaled nitric oxide (iNO).

While caffeine has been associated with improvement in BPD (15) and neurodevelopmental outcomes (16) [unfortunately, not sustained at 5 years of age (17)], studies fine-tuning the timing of initiation and duration of use of this drug would be useful. This is important given the fact that the mechanism of action in terms of the pulmonary effects in the developing lung is not currently understood and toxicity concerns have been raised in an animal study (18). Despite a large number of infants being studied in randomized clinical trials (RCTs), iNO has not been consistently found to be beneficial in preventing BPD and is currently not recommended for such treatment $(19,20)$. It is therefore critical that for both caffeine and iNO, given past experience, subgroup targeted therapy (21) should be tested in future RCTs. Such targeted subgroups could be on the basis of genotype or phenotype (for e.g., small for gestational age infants) criteria. Assessment of genotypes would be a useful technique to identify specific populations most likely to benefit from such a targeted approach, which would incorporate the not insignificant effects of the genetic contribution to BPD (1, 22-24).

On searching the clinicaltrials.gov database with the terms "drugs" and "BPD" (accessed on May 15, 2014; including only "open" studies that are actively recruiting; excluding those with "unknown status"), 24 studies were identified. Among these, those with specific drug therapy with the primary or secondary outcome listed as assessment of BPD included caffeine (1 trial), recombinant human Clara Cell $10 \mathrm{kDa}$ protein (1 trial), iNO (2 trials), macrolide antibiotics (2 trials), hydrocortisone ( 2 trials), vitamin D ( 1 trial), remifentanil (1 trial), appropriate levels of oxygen ( 1 trial), maternal $N$-acetyl cysteine ( 1 trial), maternal enoxaparin ( 1 trial), and L-thyroxine (1 trial).

While awaiting the results of these clinical trials over the next few years, it is important that currently used drugs (approved for use in non-BPD medical conditions) be also tested and new drugs be developed to target novel molecular targets that have been identified in studies conducted in animal models of BPD (25). This becomes especially important since the incidence of BPD appears to be the same or slightly increased (25), despite the continuing use of non-invasive ventilation strategies (26). For translational impact, molecular targets that have been identified to be associated with human BPD would have the maximal potential to be of clinical use. Such potential therapies include anti-interleukin-1 (anakinra) 
(27), inhibition of Cox-2 and C/EBP homologous protein (CHOP) (celecoxib) $(28,29)$, targeting transforming growth factor-beta 1 signaling (losartan) (30), matrix proteins [elastase (elafin) (31), matrix metalloproteinase-9 (doxycycline) (28)], augmentation of the parathyroid hormone-related protein-peroxisome proliferator-activated receptor-gamma pathway (rosiglitazone, pioglitazone) (32, 33), modulation of macrophage migration inhibiting factor (34-36), and chitinase3 -like protein 1 (37, 38). Appropriate protocols for testing such drugs and/or their safer analogs in the preterm newborn population would need to be developed and it is imperative that data from studies conducted in older children and adults not be interpolated to the neonatal subjects, but independently verified. Strategies that incorporate drug delivery confined to the pulmonary compartment would minimize off-target effects (including untoward effects) and maximize the therapeutic response. For this to occur, given the current fiscal climate of federal funding, it is imperative that private philanthropic foundations with an interest in improving the health of children as well as pharmaceutical companies step up to the plate to partner with innovative physicianscientists to support pre-clinical/phase-1 studies of such drug therapies.

\section{REFERENCES}

1. Bhandari V, Bizzarro MJ, Shetty A, Zhong X, Page GP, Zhang H, et al. Familial and genetic susceptibility to major neonatal morbidities in preterm twins. Pediatrics (2006) 117(6):1901-6. doi:10.1542/peds.2005-1414

2. Bhandari A, Bhandari V. Pitfalls, problems, and progress in bronchopulmonary dysplasia. Pediatrics (2009) 123(6):1562-73. doi:10.1542/peds. 2008-1962

3. Bhandari A, Bhandari V. "New" bronchopulmonary dysplasia - a clinical review. Clin Pulm Med (2011) 18:137-43. doi:10.1097/CPM. 0b013e318218a071

4. Stroustrup A, Trasande L. Epidemiological characteristics and resource use in neonates with bronchopulmonary dysplasia: 1993-2006. Pediatrics (2010) 126(2):291-7. doi:10.1542/peds.2009-3456

5. Smith VC, Zupancic JA, McCormick MC, Croen LA, Greene J, Escobar GJ, et al. Trends in severe bronchopulmonary dysplasia rates between 1994 and 2002. J Pediatr (2005) 146(4):469-73. doi:10. 1016/j.jpeds.2004.12.023

6. Trembath A, Laughon MM. Predictors of bronchopulmonary dysplasia. Clin Perinatol (2012) 39(3):585-601. doi:10.1016/j.clp.2012.06.014
7. Jensen EA, Schmidt B. Epidemiology of bronchopulmonary dysplasia. Birth Defects Res A Clin Mol Teratol (2014) 100(3):145-57. doi:10.1002/ bdra. 23235

8. Johnson TJ, Patel AL, Jegier BJ, Engstrom JL, Meier PP. Cost of morbidities in very low birth weight infants. J Pediatr (2013) 162(2):243-49.e1. doi:10.1016/j.jpeds.2012.07.013

9. Bhandari A, Panitch HB. Pulmonary outcomes in bronchopulmonary dysplasia. Semin Perinatol (2006) 30(4):219-26. doi:10.1053/j.semperi.2006. 05.009

10. Anderson PJ, Doyle LW. Neurodevelopmental outcome of bronchopulmonary dysplasia. Semin Perinatol (2006) 30(4):227-32. doi:10.1053/j.semperi. 2006.05.010

11. Greenough A, Alexander J, Boorman J, Chetcuti PA, Cliff I, Lenney W, et al. Respiratory morbidity, healthcare utilisation and cost of care at school age related to home oxygen status. Eur J Pediatr (2011) 170(8):969-75. doi:10.1007/s00431-010-1381-6

12. Landry JS, Croitoru D, Jin Y, Schwartzman K, Benedetti A, Menzies D. Health care utilization by preterm infants with respiratory complications in Quebec. Can Respir J (2012) 19(4):255-60.

13. Gough A, Linden M, Spence D, Patterson CC, Halliday HL, McGarvey LP. Impaired lung function and health status in adult survivors of bronchopulmonary dysplasia. Eur Respir J (2014) 43(3):808-16. doi:10.1183/09031936.00039513

14. McEvoy CT, Jain L, Schmidt B, Abman S, Bancalari E, Aschner JL. Bronchopulmonary dysplasia: NHLBI workshop on the primary prevention of chronic lung diseases. Ann Am Thorac Soc (2014) 11(Suppl 3):S146-53. doi:10.1513/ AnnalsATS.201312-424LD

15. Schmidt B, Roberts RS, Davis P, Doyle LW, Barrington $\mathrm{KJ}$, Ohlsson A, et al. Caffeine therapy for apnea of prematurity. $N$ Engl J Med (2006) 354(20):2112-21. doi:10.1056/NEJMoa054065

16. Schmidt B, Roberts RS, Davis P, Doyle LW, Barrington $\mathrm{KJ}$, Ohlsson $\mathrm{A}$, et al. Long-term effects of caffeine therapy for apnea of prematurity. $N$ Engl J Med (2007) 357(19):1893-902. doi:10.1056/ NEJMoa073679

17. Schmidt B, Anderson PJ, Doyle LW, Dewey D, Grunau RE, Asztalos EV, et al. Survival without disability to age 5 years after neonatal caffeine therapy for apnea of prematurity. JAMA (2012) 307(3):275-82. doi:10.1001/jama.2011.2024

18. Dayanim S, Lopez B, Maisonet TM, Grewal S, Londhe VA. Caffeine induces alveolar apoptosis in the hyperoxia-exposed developing mouse lung. Pediatr Res (2014) 75(3):395-402. doi:10.1038/pr. 2013.233

19. Cole FS, Alleyne C, Barks JD, Boyle RJ, Carroll JL, Dokken D, et al. NIH consensus development conference statement: inhaled nitric-oxide therapy for premature infants. Pediatrics (2011) 127(2):363-9. doi:10.1542/peds.2010-3507

20. Kumar P. Use of inhaled nitric oxide in preterm infants. Pediatrics (2014) 133(1):164-70. doi:10. 1542/peds.2013-3444

21. Davis PG, Schmidt B, Roberts RS, Doyle LW, Asztalos E, Haslam R, et al. Caffeine for apnea of prematurity trial: benefits may vary in subgroups. $J$ Pediatr (2010) 156(3):382-7. doi:10.1016/j.jpeds. 2009.09.069
22. Lavoie PM, Pham C, Jang KL. Heritability of bronchopulmonary dysplasia, defined according to the consensus statement of the national institutes of health. Pediatrics (2008) 122(3):479-85. doi:10.1542/peds.2007-2313

23. Prencipe G, Auriti C, Inglese R, Devito R, Ronchetti MP, Seganti G, et al. A polymorphism in the macrophage migration inhibitory factor promoter is associated with bronchopulmonary dysplasia. Pediatr Res (2011) 69(2):142-7. doi:10.1203/PDR. 0b013e3182042496

24. Fujioka K, Shibata A, Yokota T, Koda T, Nagasaka $\mathrm{M}$, Yagi $\mathrm{M}$, et al. Association of a vascular endothelial growth factor polymorphism with the development of bronchopulmonary dysplasia in Japanese premature newborns. Sci Rep (2014) 4:4459. doi:10.1038/srep04459

25. Bhandari V. Postnatal inflammation in the pathogenesis of bronchopulmonary dysplasia. Birth Defects Res A Clin Mol Teratol (2014) 100(3):189-201. doi:10.1002/bdra.23220

26. Bhandari V. The potential of non-invasive ventilation to decrease BPD. Semin Perinatol (2013) 37(2):108-14. doi:10.1053/j.semperi.2013.01.007

27. Nold MF, Mangan NE, Rudloff I, Cho SX, Shariatian N, Samarasinghe TD, et al. Interleukin-1 receptor antagonist prevents murine bronchopulmonary dysplasia induced by perinatal inflammation and hyperoxia. Proc Natl Acad Sci US A (2013) 110(35):14384-9. doi:10.1073/pnas.1306859110

28. Harijith A, Choo-Wing R, Cataltepe S, Yasumatsu $\mathrm{R}$, Aghai $\mathrm{ZH}$, Janer J, et al. A role for matrix metalloproteinase 9 in IFNgamma-mediated injury in developing lungs: relevance to bronchopulmonary dysplasia. Am J Respir Cell Mol Biol (2011) 44(5):621-30. doi:10.1165/rcmb.20100058OC

29. Choo-Wing R, Syed MA, Harijith A, Bowen B, Pryhuber G, Janer C, et al. Hyperoxia and interferongamma-induced injury in developing lungs occur via cyclooxygenase- 2 and the endoplasmic reticulum stress-dependent pathway. Am J Respir Cell Mol Biol (2013) 48(6):749-57. doi:10.1165/rcmb. 2012-0381OC

30. Li Z, Choo-Wing R, Sun H, Sureshbabu A, Sakurai $\mathrm{R}$, Rehan VK, et al. A potential role of the JNK pathway in hyperoxia-induced cell death, myofibroblast transdifferentiation and TGF-betal-mediated injury in the developing murine lung. $B M C$ Cell Biol (2011) 12(1):54. doi:10.1186/1471-212112-54

31. Hilgendorff A, Parai K, Ertsey R, Juliana ReyParra G, Thebaud B, Tamosiuniene R, et al. Neonatal mice genetically modified to express the elastase inhibitor elafin are protected against the adverse effects of mechanical ventilation on lung growth. Am J Physiol Lung Cell Mol Physiol (2012) 303(3):L215-27. doi:10.1152/ajplung. 00405.2011

32. Rehan VK, Torday JS. Exploiting the PTHrP signaling pathway to treat chronic lung disease. Drugs Today (Barc) (2007) 43(5):317-31. doi:10.1358/ dot.2007.43.5.1062665

33. Morales E, Sakurai R, Husain S, Paek D, Gong M, Ibe B, et al. Nebulized PPARgamma agonists: a novel approach to augment neonatal lung maturation and injury repair in rats. Pediatr Res (2014) 75(5):631-40. doi:10.1038/pr.2014.8 
34. Sun H, Choo-Wing R, Fan J, Leng L, Syed MA, Hare AA, et al. Small molecular modulation of macrophage migration inhibitory factor in the hyperoxia-induced mouse model of bronchopulmonary dysplasia. Respir Res (2013) 14:27. doi:10. 1186/1465-9921-14-27

35. Sun H, Choo-Wing R, Sureshbabu A, Fan J, Leng L, $\mathrm{Yu} \mathrm{S}$, et al. A critical regulatory role for macrophage migration inhibitory factor in hyperoxia-induced injury in the developing murine lung. PLOS One (2013) 8(4):e60560. doi:10.1371/journal. pone. 0060560

36. Fan C, Rajasekaran D, Syed MA, Leng L, Loria JP, Bhandari V, et al. MIF intersubunit disulfide mutant antagonist supports activation of CD74 by endogenous MIF trimer at physiologic concentrations. Proc Natl Acad Sci U S A (2013) 110(27):10994-9. doi:10.1073/pnas.1221817110
37. Sohn MH, Kang MJ, Matsuura H, Bhandari V, Chen NY, Lee CG, et al. The chitinase-like proteins breast regression protein-39 and YKL-40 regulate hyperoxia-induced acute lung injury. Am J Respir Crit Care Med (2010) 182(7):918-28. doi:10.1164/ rccm.200912-1793OC

38. Syed MA, Bhandari V. Hyperoxia exacerbates postnatal inflammation-induced lung injury in neonatal BRP-39 null mutant mice promoting the M1 macrophage phenotype. Mediators Inflamm (2013) 2013:457189. doi:10.1155/2013/ 457189

Conflict of Interest Statement: The author declares that the research was conducted in the absence of any commercial or financial relationships that could be construed as a potential conflict of interest.
Received: 16 May 2014; paper pending published: 16 June 2014; accepted: 06 July 2014; published online: 25 July 2014.

Citation: Bhandari V (2014) Drug therapy trials for the prevention of bronchopulmonary dysplasia: current and future targets. Front. Pediatr. 2:76. doi: 10.3389/fped.2014.00076

This article was submitted to Neonatology, a section of the journal Frontiers in Pediatrics.

Copyright (c) 2014 Bhandari. This is an open-access article distributed under the terms of the Creative Commons Attribution License (CC BY). The use, distribution or reproduction in other forums is permitted, provided the original author(s) or licensor are credited and that the original publication in this journal is cited, in accordance with accepted academic practice. No use, distribution or reproduction is permitted which does not comply with these terms. 